\title{
Concealing Financial Distress With Earnings Management: A Perspective on Malaysian Public Listed Companies
}

\author{
Mohamad Ezrien Bin Mohamad Kamal ${ }^{1} \&$ Siti Sarah Binti Khazalle ${ }^{1}$ \\ ${ }^{1}$ Faculty of Accountancy, Universiti Teknologi MARA, Malaysia \\ Correspondence: Mohamad Ezrien Bin Mohamad Kamal, Faculty of Accountancy, Universiti Teknologi MARA, \\ Malaysia.
}

Received: September 16, 2020

Accepted: November 4, 2020

Online Published: January 19, 2021

doi:10.5430/ijfr.v12n2p341

URL: https://doi.org/10.5430/ijfr.v12n2p341

\begin{abstract}
Earnings Management is prevalent among corporations, resulting to misleading information disclosed on financial statements. By adopting agency theory argument, in line with fulfilling shareholders expectations on financial performance while securing their position and interest within the company, management may be influenced to engage earnings management when the actual financial outcome is in financial distress. Hence, this study attempts to identify whether companies listed on Industrial Product sector of Malaysian Bourse experienced financial distress condition and embark on earnings management. It also examines potential relationship between financial distress conditions and earnings management within the context of companies listed within Industrial Product sector of Malaysian Bourse in 2016 and 2017. Industrial Product sector was chosen as focus of this study due to its critical position in nation's transformation to become developed country and as the main contributor to the nation's GDP with largest market capitalization value in local bourse. Financial distress was proxied by Altman $\mathrm{Z}$ score and earnings management by discretionary accruals as per Kothari (2005). The study was conducted using the quantitative statistical method by running multiple regressions in SPSS version 23. The study also included three control variables, such as firm size, financial leverage and free cash flow from operation. The sample of this study comprised of 454 firms of Industrial Products Sector, listed on Malaysian Bourse from 2016 to 2017. The result revealed significant negative relationship between financial distress and earnings management by companies within Industrial Product sector. Financial leverage and free cash flow from operation have inverse relationship with earnings management, while firm size has a positive relationship with earnings management. This also means management of Industrial Product Sector companies engage earnings management when their financial condition is not in distress, hence they are not using earnings management to conceal financial distress condition. Instead they may use earnings management to leverage on their non-distress financial condition to attain better share price performance and financing arrangement.
\end{abstract}

Keywords: discretionary accruals, earnings management, financial distress, financial leverage, firm's size, free cash flow from operation

\section{Introduction}

Earnings Management practice can lead to misleading financial statements, despite manipulatively fulfilling market expectations of company's performance to increase its share price (Agrawal \& Chatterjee, 2015; Kamal, Salleh \& Ahmad, 2019). It has been identified as the main culprit leading to catastrophic fraudulent financial reporting scandals worldwide, with huge losses suffered by shareholders amounting to billions of dollars (Dharan \& Bufkins, 2008). For instance, fraudulent financial reporting in Enron Corporation started from early earning management practice, which later grew into a catastrophic financial disaster (Abd, Aziz, \& Kassem, 2010; Dharan \& Bufkins, 2008). It is also possible to commit earnings manipulation due to information asymmetry created from agency problems (Jensen, 1986; Jensen \& Meckling, 1976) and the loopholes in the accounting standard and regulations from flexibility of choosing available accounting methods (Ghazali et al., 2015; Hasnan, Rahman, \& Mahenthiran, 2014; Healy \&Wahlen, 1999; Jensen \& Meckling, 1976). Earnings management is defined as intervention by the company's management via earning adjustment by utilising accounting techniques on financial statements to meet specific targeted outcome (Dechow \& Skinner, 2000; Dechow, Sloan, \& Sweeney, 1995; Ghazali et al., 2015; Schipper, 1989). Furthermore, cases of earnings manipulation also took place among public listed companies on 
Bursa Malaysia (Ghazali et al., 2015; Rahman, Sulaiman, Fadel, \& Kazemian, 2016; Sadique, 2016). The main drive for earnings management can be explained by using Agency Theory argument as posed by Jensen \& Meckling (1976). For instance, in line with fulfilling shareholders expectations on financial performance while securing their position and interest within the company, management may be influenced to engage earnings management when the actual financial outcome is in financial distress. This is achieved when financially distressed company's managers tend to inflate operating income more likely than healthy firms to achieve or beat earnings target (Nagar \& Sen, 2016). Several prior researches have been conducted to assess relationship between financial distress and earnings management. Nevertheless the results were not consistent and mixed with some showing significant negative relationship (Agrawal \& Chatterjee, 2015; Ghazali et al., 2015; Kazemian, Shauri, Sanusi, Kamaluddin, \& Shuhidan, 2017; Mohammadi \& Amini, 2016; Nagar \& Sen, 2016; Qin \& Ren, 2017) and others significant positive (Hassanpour \& Ardakani, 2017; Muljono \& Suk, 2018), and no relationship (Humeedat , 2018). Furthermore, no such study in the past had focused mainly on companies listed on Industrial Product Sector of Bursa Malaysia, despite being critical in nation's transformation to become developed country and as the main contributor to the nation's GDP with largest market capitalization value in local bourse (Statista, 2016). Most of these researches were also conducted externally, where such studies within local context are still limited and open for further investigation. Hence, this study attempts to identify whether companies listed on Industrial Product sector of Malaysian Bourse experienced financial distress condition and embark on earnings management. It also examines potential relationship between financial distress conditions and earnings management within the context of companies listed within Industrial Product sector of Malaysian Bourse in 2016 and 2017.

\section{Literature Review, Hypotheses Development and Research Framework}

Several prior studies in the past had been done to assess potential relationship between financial distress and earnings management with mixed results of negative connections (Agrawal \& Chatterjee, 2015; Ghazali et al., 2015;Kazemian, Shauri, Sanusi, Kamaluddin, \& Shuhidan, 2017; Mohammadi \& Amini, 2016; Nagar \& Sen, 2016; Qin \& Ren, 2017) and positive relationships (Muljono \& Suk, 2018; Hassanpour \& Ardakani, 2017). Hassanpour and Ardakani (2017) studied the effect of pre-bankruptcy financial distress on earnings management for 133 Tehran Stock Exchange listed companies for five (5) consecutive years from 2010 to 2014. They adopted descriptive-correlational research to investigate the financial distress relationship and free cash flow position with earnings management and found positive significant relationship for both with earnings management. Another related study was conducted by Mohammadi and Amini (2016), with the objective of assessing the relationship between financial distress and earnings management of companies listed in the Tehran Stock Exchange during the period from 2008 to 2015. The result revealed significant negative relationship between earnings management and non-financial distress where earnings management will increase with the increase in free cash flow as a measurement of financial distress. Findings from the study made by Ghazali et al. (2015) provided additional evidence that supports Mohammadi \& Amini (2016). The study selected sample of 1166 firm years of Public Listed Companies in Malaysia from 2010 to 2012 which was analysed using multiple linear regressions. The result revealed significant negative relationship between financial distress and earnings management, which also mean when a company is financially healthy, it may engage in earnings management. Agrawal and Chatterjee (2015) studied the relationship between earnings management and financial distress for a sample of 150 financially distressed firms in India from 2009 to 2014. They adopted Altman Z score and distance-to-default to measure the financial conditions of the firms. The result revealed significant negative relationship which means less distressed firms engaged in higher earnings management. Opposite to Agrawal and Chatterjee (2015)'s finding, Nagar and Sen (2016) study revealed that the higher the distress risk of the company, the higher the likelihood that the manager will engage in earnings management. In addition, another study made by Qin and Ren (2017) revealed that manager will be involved in income-deflating discretionary accruals when the distress risk increases in the company. The sample used in the study was collected from the COMPUSTAT/CRSP merged database from years 1975 to 2015, excluding the utility and financial firms Earnings Management and Control Variables. This however is not consistent with Muljono \& Suk, (2018)'s findings which revealed significant positive relationship between financial distress and discretionary component of accrual. The later had studied a total of 2002 firm-year observations from 259 public listed companies in Indonesia from 2005 to 2014.Humeedat (2018), also conducted a study on role of earnings management to avoid financial distress and decline in profitability. A sample of 413 observations from 58 corporations listed on Amman Stock exchange were selected from 2011 to 2016. Nevertheless, the finding revealed no significant relationship between Earnings Management and Financial Distress. Hence, the following hypothesis $\mathrm{H}_{1}$ is formed based on the above arguments:

$\mathrm{H}_{1}$ : Relationship exists between financial distress and earning management practice of Industrial Product sector's 
companies

\subsection{Earnings Management and Free Cash Flow From Operations}

Free cash flow from operations, which is one of control variables used in this study represents excess cash flow obtained by a company from its revenue generated from the operation after deducting all other operation expenses related to the company (Nobanee \& Abraham, 2017). It refers to excess funds available after financing profitable projects which risk of being wasted into unprofitable project (Jensen, 1986). Such investment in unprofitable project may lead to counter-performance which managers will try to conceal via earnings management (Rusmin, Astami\&Hartadi, 2014).Bukit and Nasution (2015) studied the relationship of free cash flow from operation and earnings management on companies listed at Indonesian stock market from 2011 to 2013 and grouped them into less intensive and intensive companies. The result revealed companies tend to manipulate earnings when there is an excess of free cash flow in less intensive companies. This was also suported by Dewi and Priyadi (2016)who analysed the relationship of free cash flow from operations and earnings management of non-financial companies listed on Indonesian Stock Exchange from 2010 to 2014, with significant positive results. Other studies which revealed positive results were conducted by Barkhordar and Tehrani (2016). They had studied the relationship between free cash flow from operations and earnings management of 89 companies listed on Tehran Stock Exchange from 2004 to 2013 and found significant positive result. Nevertheless, some studies had revealed negative relationship between free cash flow from operations and Earnings Management, namely studies by Agustia (2013) and, Yogi and Damayanthi (2016). Agustia (2013) had analysed a sample of 14 companies from the textile industry listed under the Indonesian Stock Exchange from 2007 to 2011, and found that an excess of free cash flow from operations will lead to decrease in earnings management. Similar result was obtained by Yogi and Damayanthi (2016) who did similar study but focused on financial institutions listed on Indonesian Stock Exchange, with significant positive relationship identified. This however contradicted the study done on sample of non-financial companies listed on Indonesian Stock Exchange from 2010 to 2014 by Dewi and Priyadi (2016) who revealed negative connection.Hence, the following hypothesis is formulated based on the above arguments relating to relationship between free cash flow from operations and earnings management as follows:

$\mathrm{H}_{2}$ : Relationship exists between Free Cash Flow from Operations (FCFFO) and Earnings Management practice of Industrial Product sector's companies.

\subsection{Earnings Management and Financial Leverage}

Financial leverage which is proxied by debt ratio and categorized as control variable in this study is expected to influence management incentives to engage in earnings management. In previous studies, there were mixed results on the relationship between debt covenant and earnings management as follows.In a study made by DeAngelo, DeAngelo, and Skinner (1994) the findings showed that the company will recognize their situation of financial distress instead of inflate their earnings through discretionary accrual to avoid debt covenant violations or to conceal their financial difficulty. The study was made on the sample of NYSE non-financial companies which reported losses in multiple years and had dividend reductions from 1980 to 1985. In a recent study in Malaysia on the relationship between financial distress and leverage, a significant relationship was found. This means that leverage can affect the financial situation condition of a firm and give impact to the accounting policy selected by the management to manipulate earnings (Kazemian et al., 2017). Further study was done by DeFond and Jiambalvo (1994) and Sweeney (1994) to analyse the relationship between debt covenant violation and earnings management among sample of companies that had violated their debt covenant. The former study found that earnings were adjusted a year prior to the debt covenant violation while the later study revealed company adjusted their earnings after the debt covenant violation. Another study was carried out on sample of companies listed on Tehran Stock Exchange by Mohammadi and Amini (2016) which revealed positive significant relationship between earnings management and financial leverage. This is also supported by Ghazali et al. (2015) who conducted similar study in Malaysia and found significant positive relationship between leverage and earnings management.

A recent study made by Agrawal and Chatterjee (2015) also showed positive significant relationship between leverage and earnings management which was similar to the study and result discovered by Humeedat (2018). The study sample included 58 companies of the industrial sector listed in the Amman Stock Exchange from years 2011 to 2015. Following study on relationship between financial leverage with real and accrual earnings management was done by Anagnostopoulou and Tsekrekos (2017). It was found that the engagement in earnings management involving real earnings is more significant and positive if the financial leverage is high. Thus, with high leverage, companies tended to engage more in real earnings management compared to accrual earnings management (Anagnostopoulou \& Tsekrekos, 2017). It was also found that the accrual earnings management and real earnings 
management complement each other when high leverage firm is believed to get more scrutiny from outsiders, leading to the engagement in both real and accrual based earnings management (Anagnostopoulou \& Tsekrekos, 2017). Hence, the following hypothesis is formulated based on the above arguments relating to relationship between free cash flow from operations and earnings management as follows:

$\mathrm{H}_{3}$ : Positive Relationship exists between Leverage and Earnings Management practice of Industrial Product sector's companies

\subsection{Earnings Management and Firm Size}

Pressure to report positive earnings is more for firms with large size since they hold more abilities to negotiate with auditors, more options of selecting suitable accounting treatments, and higher management influence to engage earnings management (Kim, Liu \& Rhee, 2003). In line with this, Kim et al. (2003) had examined the relationship between corporate earnings and firms size on all companies available from Compustat database from 1983 to 2000. The results revealed more aggressive earnings management being exhibited by large and medium sized firms as compared to small sized firms. This is also supported by Darmawan (2015), who studied a sample of manufacturing companies listed on Indonesian Stock Exchange from 2013 to 2015 and found positive significant relationship between firm size and earnings management. Another study by Ali, Noor, Khurshid, \& Mahmood, (2015) also discovered positive significant relationship between firm size and earnings management on textile companies in Pakistan from 2004 to 2013. This contradicts the findings made by Astuti, Nuraina, and Wijaya, (2017) who studied banking companies listed on Indonesian Stock Exchange from 2013 to 2015. The results revealed no effect between firm size and earnings management. The result from the study by Astuti et al. (2017) was different than Darmawan (2015) may be due to differences in types of industry as both have different laws and accounting policies to abide with. Findings by Astuti et al. (2017)was echoed in Llukani, (2013) who analysed the relationship of earnings management and firm size of 75 private sector companies in Albania. They found the relationship not significant and companies engage in earnings management irrespective of firm size. Hence, this study adopts firm size as one of the control variables to examine the relationship between financial distress and earnings management. Based on the above notions, the following hypothesis is developed.

$\mathrm{H}_{4}$ : Relationship exists between Firm size and Earnings Management practice of Industrial Product sector's companies

\subsection{Research Framework}

The main objective of this study is to assess whether companies from industrial product sector of Malaysian bourse experienced financial distress condition which lead them to engage in earnings management practice. In another words, this study focuses on determining potential relationship between financial distress condition and earnings management practice by Malaysian Industrial Product companies. Three control variables were also included in this study comprising of free cash flow, firm size and financial leverage as they had shown significant effect on earnings management in prior studies. Figure 1 shows the research framework of the current study.

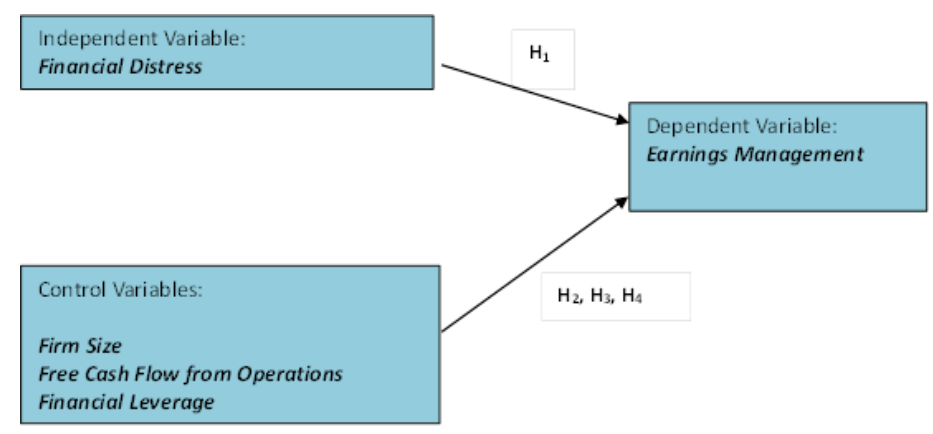

Figure 1. Research framework of the study

\section{Methodology}

This study adopted quantitative approach by utilising data obtained from reliable secondary source such as published annual reports of companies listed under Industrial Product Sector of Malaysian Bourse. Quantitative research can be 
described as 'empiricism' by Leach (1990) or 'positivism' by Duffy (1985), and Cormack (1991) defined it as the scientific method used in a physical science (Carr, 1994). The quantitative method is said to give an eagle's eye social phenomena view where it gives a general phenomenon on the item of interest in the study from the developed theory available (Farrelly, King, Wesley, \& White, 2017). All of the companies listed within Industrial Product Sector on Malaysian Bourse from 2016 until 2017 were taken as sample for this study. There were 462 firm-years sample for 2016 and 2017. These 2 years were selected as they happened subsequent to effective implementation of GST date on May 2015, in which most businesses were still in the midst of familiarising with the new GST system. Hence, 2016 and 2017 were considered suitable for this study as the companies were already stable in terms of implementation and recoding of GST transactions. Nevertheless, 8 firm-years were excluded from this study due to incomplete data available to calculate both Altman Z-score and discretionary accrual, leaving remaining of 454 firm-years. This represents $98 \%$ of the whole population as shown in Table 1.

Table 1. Sample selection for the study

\begin{tabular}{llll}
\hline & No of firms in 2016 & No of firms in 2017 & Total No of firms \\
\hline $\begin{array}{l}\text { Total Public Listed Company as at } 231 \\
31 / 12 / 201 x\end{array}$ & 231 & 462 \\
\hline $\begin{array}{l}\text { Less: Company removed from (4) } \\
\text { sample due to incomplete records for } \\
\text { the period of selection. }\end{array}$ & & $(4)$ \\
\hline $\begin{array}{l}\text { Total industrial products companies } 227 \\
\text { in Main Board of Bursa Malaysia }\end{array}$ & & 454 \\
used as sample
\end{tabular}

The data collection method for this study utilised secondary data obtained from annual report published in Malaysian Bourse website and from Thomson Reuters DataStream. Data collected were subject to descriptive analysis, reliability test and normality assessment to ensure all data was normally distributed. Then, Pearson correlation test was run, and multicollinearity effect was assessed, to identify potential relationship between variables. Finally, after fulfilling the conditions required for multiple regression analysis, the latter was run to assess relationships between financial distress, control variables and earnings management in line with the objectives of this study.

\subsection{Operational Definitions and Measurement}

For the purpose of this study, the dependent variable is earnings management, which is measured using the discretionary accrual. The independent variable which is the proxy of financial distress is measured by Altman- $\mathrm{z}$ score and the control variables in this study are total asset of the company, debt ratio and free cash flow from operations where it is a proxy for firm size, financial leverage and free cash flow from operations respectively.

\subsubsection{Dependent Variable: Accrual Earnings Management (AEM)}

This study uses accrual earnings management (AEM) as the dependent variable. The variable is measured based on "Performance Matched Modified Jones Model" as per Kothari (2005) which is popular in academic research. This model is also capable of giving better reliability on earnings management assessment via discretionary accruals (Kothari et al., 2005). Furthermore, it includes improved way of calculating discretionary accruals by including the performance matching on the discretionary accrual with the basis of return on assets while having the lowest Type 1 error rates. In addition to Kothari model, other popular earnings management models such as Jones model (Jones, 1991), Dechow model (Dechow et al., 1995), and Yoon model (2006) were used to compare the explanatory power of each model for the sample selected in the study. To derive on the total discretionary accruals, the following formula is used:

$$
D A_{i t}=T A_{i t}-N D A_{i t}
$$

Where:

$\mathrm{DA}_{\mathrm{it}}=$ Total discretionary accruals for the company $\mathrm{i}$ in the current period $\mathrm{t}$

$\mathrm{TA}_{\mathrm{it}}=$ Total accruals for the company $\mathrm{i}$ in the current period $\mathrm{t}$

$\mathrm{NDA}_{\mathrm{it}}=$ Total non-discretionary accruals for the company $\mathrm{i}$ in the current period $\mathrm{t}$. 
For the calculation of total non-discretionary accrual, the Kothari model (2005) was used in this study as below:

$$
N D A_{i, t}=\hat{\alpha}_{1}\left(\frac{1}{A S S E T_{i, t-1}}\right)+\hat{\alpha}_{2}\left(\frac{\Delta R E V_{i, t}-\Delta R E C_{i, t}}{A S S E T_{i, t-1}}\right)+\hat{\alpha}_{3}\left(\frac{P P E_{i, t}}{A S S E T_{i, t-1}}\right)+\hat{\alpha}_{4} R O A_{i, t-1}
$$

Where:

$N D A_{i, t}=$ Total non-discretionary accruals for the company $\mathrm{i}$ in current year, $\mathrm{t}$

$\triangle R E V_{i, t}=$ Net sales revenue for the company $\mathrm{i}$ in current year, $\mathrm{t}$ less net sales revenue for the company $\mathrm{i}$ in year, $\mathrm{t}-1$.

$\triangle R E C_{i, t}=$ Receivables for the company $\mathrm{i}$ in current year, $\mathrm{t}$ less receivables for the company $\mathrm{i}$ in year $\mathrm{t}-1$

$\triangle R E C_{i, t}=$ Gross property plant and equipment in year $\mathrm{t}$

$R O A_{i, t-1}=$ Return on Asset for company $\mathrm{i}$ in year $\mathrm{t}-1$.

\subsubsection{Independent Variable: Financial Distress}

Financial distress represents a state where firms face financial difficulties with respect to poor cash flows and profitability. At this point, the companies might not be able to maintain their business operations on a day-to-day basis due to cash flow problems. The injection of more capital will increase the leverage rate which will then increase the risk of bankruptcy (Altman, 2000; Kazemian et al., 2017; Mohammadi \& Amini, 2016; Nagar \& Sen, 2016; Persons, 2011; Qin \& Ren, 2017). The measurement used for this study was the Altman-Z score where the latest model for the manufacturing firms was used to measure the financial distress situation of the companies (Altman, 2000). According to Altman (2000), companies can be classified under three conditions based on the results, in which companies with lower than 1.80 score are classified as likely to be bankrupt or in financial distress, while if the score is above 3.0, it means that the company is healthy. Lastly, if the company's score is between 1.81 to 3.0 , the company is classified as unpredictable, which is in the grey area. The formula can be written as below:

$$
Z-\text { score }=1.2 *\left(\frac{W C}{T A}\right)+1.4 *\left(\frac{R E}{T A}\right)+3.3 *\left(\frac{E B I T}{T A}\right)+0.6 *\left(\frac{M V E}{T L}\right)+1.0 *\left(\frac{S}{T A}\right)
$$

Where:

$W C=$ Working Capital;

$T A=$ Total Assets;

$R E=$ Retained Earnings;

$E B I T=$ Earnings before Interest and Taxes;

$M V E=$ Market Value of Equity;

$T L=$ Total Liabilities;

$S=$ Sales.

\subsubsection{Control Variables: Firm Size}

The size of a firm is determined based on the capital utilised by the company to generate income as it determines the limit and extent by the firm in allocating its resources for generating its income (Dang et al., 2018; Mohammadi \& Amini, 2016; Rahman et al., 2016). The measurement of the firm's size in this study will be the "Total Assets" as it is widely used in most academic researches (Dang et al., 2018).

\subsubsection{Control Variables: Financial Leverage}

Financial leverage can be defined as the amount of total debt the company has to meet in the future and included as debt in its capital structure (Bhardwaj, 2018). The financial leverage of a company can be measured by calculating the Debt Ratio which can be derived by dividing "Total Debt to Total Assets". It determines the total proportion of asset financed by debt in the companies.

\subsubsection{Control Variables: Free Cash Flow From Operation}

Free cash flow is the amount of cash that is not used or is in excess that is held by the company in their books of account. This is excess cash after all the operating expenses and obligations have been paid by the company and it comes from the revenues that the company generates through their operation activities. It is the total operating cash flow and this amount does not affect the operation of the companies as it is an idle amount kept (Humeedat, 2018; Mohammad, Bassam, Maali, \& Al-Attar, 2017; Qin \& Ren, 2017; Rahman, Sulaiman, Fadel, \& Kazemian, 2016). 


\section{Results and Discussion}

For the purpose of this study, the sample data selected must be normally distributed to conduct a parametric test. The results from the normality test conducted found that there were no violations on the assumption of normality for earnings management, financial distress, financial leverage, firm size and free cash flow from operation in 2016 and 2017. Descriptive test on the sample was later performed to assess both Earnings Management practice and financial distress condition among Industrial Product sector companies in 2016 and 2017 as seen in Table 2 and Table 3 respectively.

Table 2. Earnings management in companies listed on industrial product sector of bursa Malaysia's main board

\begin{tabular}{|c|c|c|c|c|c|c|c|c|}
\hline \multirow[t]{2}{*}{$\begin{array}{l}\text { Companies Listed } \\
\text { on } \\
\text { Product }\end{array}$} & 2016 & & & & 2017 & & & \\
\hline & No & $\%$ & $\begin{array}{l}\text { Discretionary } \\
\text { Mean } \\
\text { (RM Million) }\end{array}$ & Accrual & No & $\%$ & $\begin{array}{l}\text { Discretionary } \\
\text { Mean } \\
\text { (RM Million) }\end{array}$ & Accrual \\
\hline $\begin{array}{l}\text { Earnings } \\
\text { Management }\end{array}$ & 149 & 66 & 27.08 & & 145 & 64 & 40.86 & \\
\hline $\begin{array}{l}\text { Non-Earnings } \\
\text { Management }\end{array}$ & 78 & 34 & $(48.44)$ & & 82 & 36 & $(47.68)$ & \\
\hline Total & 227 & 100 & & & 227 & 100 & & \\
\hline
\end{tabular}

Table 2 revealed that majority of Malaysian bourse's Industrial Product sector companies engaged in earnings management in 2016 and 2017, at the rate of $66 \%$ and 64\% respectively. The average amount of earnings management being devised as measured by discretionary accruals was RM 27.08 million in 2016 and increased rapidly by $50.8 \%$ to RM 40.86 million in 2017. This means, despite a reduction of number of companies within the sector that committed earnings management by $2.6 \%$ in 2017 , the amount crafted to devise such scheme had increased tremendously. This is definitely a worrying trend that requires further attention.

Table 3. Financial distress in companies listed on the industrial product sector list of bursa Malaysia's main board

\begin{tabular}{|c|c|c|c|c|c|c|}
\hline \multirow{2}{*}{$\begin{array}{l}\text { Companies Listed On Industrial } \\
\text { Product Sector Of Bursa } \\
\text { Malaysia's Main Board }\end{array}$} & \multicolumn{3}{|l|}{2016} & \multicolumn{3}{|c|}{2017} \\
\hline & No & $\%$ & Mean & No & $\%$ & Mean \\
\hline Non-Financial Distress & 59 & $26 \%$ & 6.29 & 59 & $26 \%$ & 4.74 \\
\hline Financial Distress & 168 & $74 \%$ & -5.20 & 168 & $74 \%$ & -8.42 \\
\hline Total & 227 & 100 & & 227 & 100 & \\
\hline
\end{tabular}

Based on Table 3, it is very clear that most of Industrial Product sector's companies were encountering financial distress condition in 2016 and 2017, at the rate of $74 \%$ for both years. The average financial distress score also showed an increase from -5.20 to -8.42 , which may mean increase in the level of severity by companies facing financial distress in 2017, despite the number of companies with financial distress condition from the sector remains stagnant in both years. Hence, Malaysian companies listed on the Industrial Product sector experienced financial distress condition in line with the findings by Aghghaleh et al. (2016); Agrawal and Chatterjee (2015); Ghazali et al. (2015); Hassanpour and Ardakani (2017); Kazemian et al. (2017); Mohammadi and Amini (2016); Nagar and Sen (2016); Quy and Nhan (2017); and Rahman et al. (2016).

In assessing potential relationship between variables in study, a correlation test was run using Pearson product moment correlation as the data is in ratio scale. Such analysis would reveal the covariance between variables, 
including the existence of multicollinearity problem. Table 4 below shows correlation results for variables used in this study.

Table 4. Correlations of matrix variables

\begin{tabular}{|c|c|c|c|c|c|c|c|}
\hline \multicolumn{3}{|c|}{ Control Variables } & EM & Z score & FCFO & FS & FL \\
\hline \multirow[t]{15}{*}{- none $^{\mathrm{a}}$} & \multirow[t]{3}{*}{ EM } & Correlation & 1.000 & -.131 & -.487 & .000 & -.112 \\
\hline & & Significance (2-tailed) & & .005 & .000 & .997 & .017 \\
\hline & & $\mathrm{df}$ & 0 & 452 & 452 & 452 & 452 \\
\hline & \multirow[t]{3}{*}{ Z score } & Correlation & -.131 & 1.000 & .259 & -.031 & -.420 \\
\hline & & Significance (2-tailed) & .005 & & .000 & .517 & .000 \\
\hline & & df & 452 & 0 & 452 & 452 & 452 \\
\hline & \multirow[t]{3}{*}{ FCFO } & Correlation & -.487 & .259 & 1.000 & .193 & -.066 \\
\hline & & Significance (2-tailed) & .000 & .000 & & .000 & .161 \\
\hline & & $\mathrm{df}$ & 452 & 452 & 0 & 452 & 452 \\
\hline & \multirow[t]{3}{*}{ FS } & Correlation & .000 & -.031 & .193 & 1.000 & .312 \\
\hline & & Significance (2-tailed) & .997 & .517 & .000 & & .000 \\
\hline & & df & 452 & 452 & 452 & 0 & 452 \\
\hline & \multirow[t]{3}{*}{ FL } & Correlation & -.112 & -.420 & -.066 & .312 & 1.000 \\
\hline & & Significance (2-tailed) & .017 & .000 & .161 & .000 & \\
\hline & & df & 452 & 452 & 452 & 452 & 0 \\
\hline \multirow{6}{*}{$\begin{array}{l}\text { FCFO \& FS \& } \\
\text { FL }\end{array}$} & \multirow{3}{*}{ EM } & Correlation & 1.000 & -.257 & & & \\
\hline & & Significance (2-tailed) & & .000 & & & \\
\hline & & df & 0 & 449 & & & \\
\hline & \multirow[t]{3}{*}{ Z score } & Correlation & -.257 & 1.000 & & & \\
\hline & & Significance (2-tailed) & .000 & & & & \\
\hline & & df & 449 & 0 & & & \\
\hline
\end{tabular}

Note: a. Cells contain zero-order (Pearson) correlations.

According to table 4, there is a negative significant correlation between Earnings Management and Financial Distress condition of Industrial Product sector's companies at .131 (p-value<0.01). This is inline with findings from Agrawal and Chatterjee (2015); Anagnostopoulou and Tsekrekos (2017); DeAngelo et al. (1994); Mohammadi and Amini (2016); Qin and Ren (2017); and Sadique (2016). Similar can be said with both FCFO and FL which showed significant negative correlation with Earnings Management at .487 (p-value<0.01) and .112 (p-value<0.05) respectively. FS however did not show any significant correlation with Earnings Management. This means that it does not matter what the size of the firm is, as earnings management will still be engaged by Industrial Product sector's companies. Furthermore, the negative correlation between Earnings Management and Financial Distress was improved further to .257 ( $\mathrm{p}$-value<0.01) from .131 when the effect of financial leverage, firm size and free cash flow from operation were controlled. This had surpassed the requirement of $r=.2$ as set by Pallant (2013) for correlation to be considered as statistically significant when there is more than 100 data $(\mathrm{N}=100+)$.

Table 5 shows the result of multicollinearity test done on all relevant variables adopted in this study. 
Table 5. Multicollinearity statistics

\begin{tabular}{|c|c|c|}
\hline & \multicolumn{2}{|c|}{ Collinearity Statistics } \\
\hline & Tolerance & VIF \\
\hline \multicolumn{3}{|c|}{ (Constant) } \\
\hline FCFO & .924 & 1.082 \\
\hline FD & .874 & 1.144 \\
\hline FL & .804 & 1.244 \\
\hline FS & .845 & 1.183 \\
\hline
\end{tabular}

Note: a. Dependent Variable: Earnings Management

This is to assess whether strong correlation existed between all variables and to eliminate issue on the trustworthiness of the $b$ coefficients and standard of error of the model used. Results showed that the variables used in this study had not encountered any multicollinearity effect as their VIF scores were less than 10 and tolerance scores were more than 0.2, in line with Field (2009). Hence, multicollinearity assumption for multiple regression analysis is fulfilled.

Further test was done to assess any potential heteroscedasticity effect in the model by analysing the scatterplot diagram between regression standardised residual and regression standardised predicted value as per figure 2 .

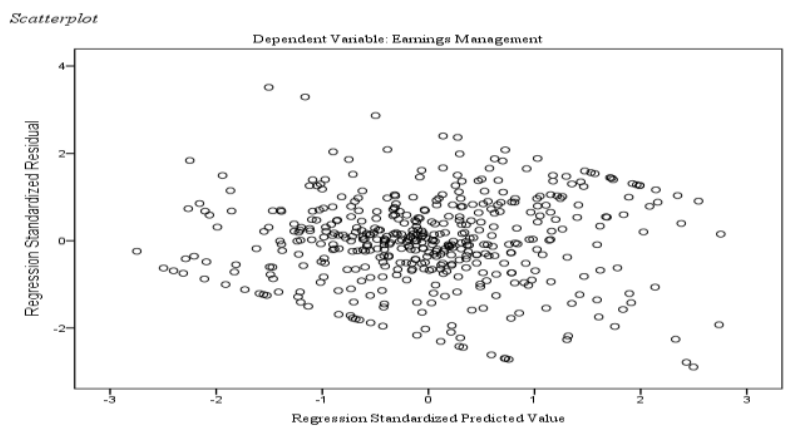

Figure 2. Scatterplot diagram on heteroscedasticity test

Based on scatter plot in Figure 2 above, there was no heteroskedasticity in the variables in the model where the assumption of multiple regressions has not been violated as the data were all homogeneous. The normality of the data must be tested as it is one of the assumptions of multiple regressions where the data must be normally distributed. The data of the residual was also normal based on the histogram in Figure 3. The linearity of the model also can be seen in the Figure 4 where the distributions of the data in the chart are not too distanced away from each other and from the linear line in the graph.

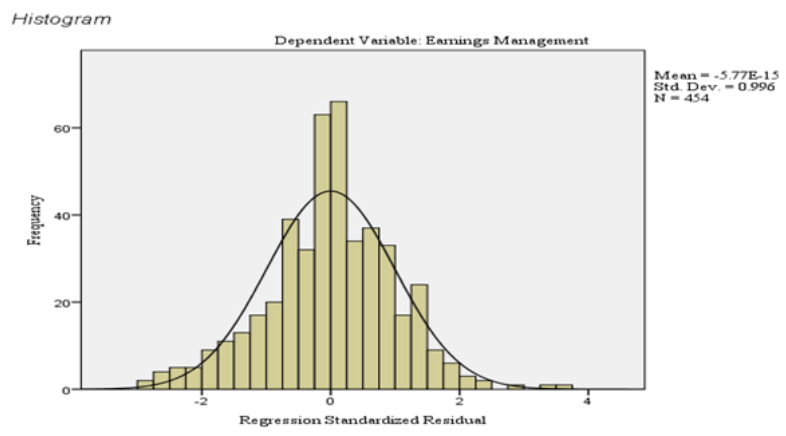

Figure 3. Histogram on normality test on multiple regression assumption 


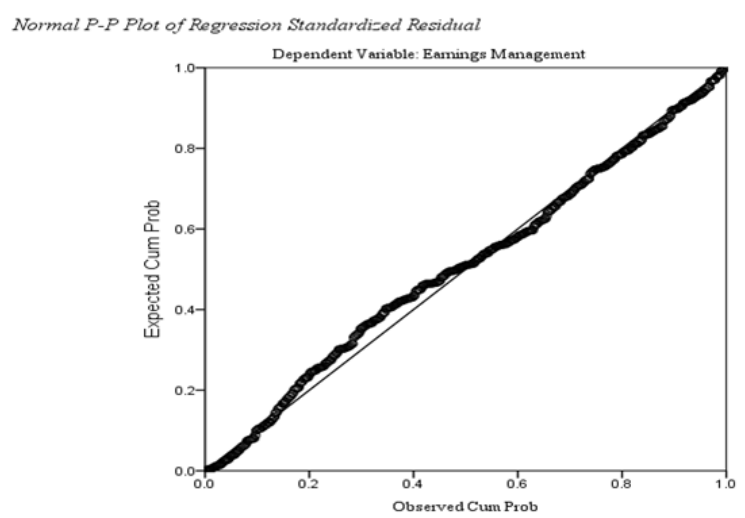

Figure 4. Normal P-P Plot of regression standardized residual

Hence, based on Figure 3 and Figure 4 above, there is no violation on the assumption of multiple regression. Autocorrelation test was run by comparing the Durbin Watson value as per table 6 to ensure there is no violation on the assumption of multiple linear regressions in the form of positive autocorrelation on the data collected.

Table 6. Durbin-watson test

\begin{tabular}{|c|c|c|c|c|c|c|c|c|c|c|}
\hline \multirow[b]{2}{*}{ Model } & \multirow[b]{2}{*}{$\mathrm{R}$} & \multirow[b]{2}{*}{$\begin{array}{l}\mathrm{R} \\
\text { Square }\end{array}$} & \multirow[b]{2}{*}{$\begin{array}{l}\text { Adjusted } \\
\text { R Square }\end{array}$} & \multirow{2}{*}{$\begin{array}{l}\text { Std. } \\
\text { Error of } \\
\text { the } \\
\text { Estimate }\end{array}$} & \multicolumn{5}{|c|}{ Change Statistics } & \multirow[b]{2}{*}{$\begin{array}{l}\text { Durbin } \\
\text { Watson }\end{array}$} \\
\hline & & & & & $\begin{array}{l}\mathrm{R} \\
\text { Square } \\
\text { Change }\end{array}$ & $\begin{array}{l}\mathrm{F} \\
\text { Change }\end{array}$ & df1 & df2 & $\begin{array}{l}\text { Sig. F } \\
\text { Change }\end{array}$ & \\
\hline 1 & $.543^{\mathrm{a}}$ & .294 & .288 & .05746 & .294 & 46.830 & 4 & 449 & .000 & 1.977 \\
\hline
\end{tabular}

Notes: a. Predictors: (Constant), FL, FCFO, FS, Z score

b. Dependent Variable: EM

The residual should be independent for each value of independent variable. Referring to Table 6 the value, DW equals to 1.977 where it was very close to 2 . This means that there was no autocorrelation on the variables in the model where the assumption of multi regression had not been violated in this study (Savin \& White, 1977).

\subsection{Multiple Regression Analysis}

Multiple linear regression analysis was used to explain the relationship between one continuous dependent variable and two or more independent variables to address the hypotheses. In this study, it was used to examine the relationship between earnings management and financial distress ( $Z$ score), financial leverage, free cash flow from operations and firm size. The multiple regression model in this study is stated as below:

$$
\mathrm{EM}=\beta_{0}+\beta_{1}(\mathrm{Z} \text { score })+\beta_{2}(\mathrm{FS})+\beta_{3}(\mathrm{FL})+\beta_{4}(\mathrm{FCFO})+€
$$

Where:

$\beta_{0}=$ the intercept;

$\beta_{1}=$ Slope for first independent variable, $\mathrm{Z}$ score;

$\beta_{2}=$ Slope for control variable, FS;

$\beta_{3}=$ Slope for control variable, FL;

$\beta_{4}=$ Slope for control variable, FCFO;

$€=$ Random error.

Table 7 below shows the model summary and the explanatory power of the model in explaining the variation in earnings management. 
Table 7. Model summary

\begin{tabular}{|c|c|c|c|c|c|c|c|c|c|c|}
\hline \multirow[b]{2}{*}{ Model } & \multirow[b]{2}{*}{$\mathrm{R}$} & \multirow[b]{2}{*}{$\begin{array}{l}\mathrm{R} \\
\text { Square }\end{array}$} & \multirow[b]{2}{*}{$\begin{array}{l}\text { Adjusted R } \\
\text { Square }\end{array}$} & \multirow{2}{*}{$\begin{array}{l}\text { Std. } \\
\text { Error of } \\
\text { the } \\
\text { Estimate }\end{array}$} & \multicolumn{5}{|c|}{ Change Statistics } & \multirow[b]{2}{*}{$\begin{array}{l}\text { Durbin- } \\
\text { Watson }\end{array}$} \\
\hline & & & & & $\begin{array}{l}\mathrm{R} \text { Square } \\
\text { Change }\end{array}$ & $\begin{array}{l}\mathrm{F} \\
\text { Change }\end{array}$ & $\begin{array}{l}\mathrm{df} \\
1\end{array}$ & df 2 & $\begin{array}{l}\text { Sig. F } \\
\text { Change }\end{array}$ & \\
\hline 1 & $.543^{\mathrm{a}}$ & .294 & .288 & .05746 & .294 & 46.830 & 4 & 449 & .000 & 1.977 \\
\hline
\end{tabular}

Notes: a. Predictors: (Constant), FL, FCFO, FS, Z score

b. Dependent Variable: EM

From the result in Table 7, the multiple regression model with all predictors produced $\mathrm{R} 2=29.4 \%, \mathrm{~F}(4,449)=46.83$ of the variation of earnings management explained by the variation of financial distress, firm size, financial leverage and free cash flow from operations. The adjusted R2 explained that $28.8 \%$ variation of earnings management was explained by considering the variation of financial distress, financial leverage, firm size and free cash flow from operation. Table 8 as follows shows the ANOVA result for the model.

Table 8. ANOVA ${ }^{\mathrm{a}}$

\begin{tabular}{llllll}
\hline & $\begin{array}{l}\text { Sum of } \\
\text { Squares }\end{array}$ & df & Mean Square & F & Sig. \\
\hline Regression & .618 & 4 & .172 & 46.830 & $.000^{\mathrm{b}}$ \\
\hline Residual & 1.482 & 449 & .003 & & \\
\hline Total & 2.101 & 453 & & & \\
\hline
\end{tabular}

Notes: a. Dependent Variable: EM

b. Predictors: (Constant), Z-score, FS, FCFO, FL

Table 8 reveals the model is very significant with at least one predictor of either $\mathrm{Z}$ score, financial leverage, free cash flow from operation and firm size in this study affected the value of earnings management at $(p<.001)$. Table 9 shows the coefficient results of every covariance in the model.

Table 9. Coefficients ${ }^{\mathrm{a}}$

\begin{tabular}{|c|c|c|c|c|c|c|c|c|}
\hline & & $\begin{array}{l}\text { Unsta } \\
\text { Coeff }\end{array}$ & $\begin{array}{l}\text { rdized } \\
\text { nts }\end{array}$ & $\begin{array}{l}\text { Standardized } \\
\text { Coefficients }\end{array}$ & & & $\begin{array}{l}95.0 \% \\
\text { Interva }\end{array}$ & $\begin{array}{l}\text { onfidence } \\
\text { B }\end{array}$ \\
\hline & & B & $\begin{array}{l}\text { Std. } \\
\text { Error }\end{array}$ & Beta & $\mathrm{t}$ & Sig. & $\begin{array}{l}\text { Lower } \\
\text { Bound }\end{array}$ & $\begin{array}{l}\text { Upper } \\
\text { Bound }\end{array}$ \\
\hline 1 & (Constant) & -.114 & .041 & & -2.789 & .006 & -.194 & -.034 \\
\hline & Z score & -.020 & .007 & -.124 & -2.933 & .004 & -.033 & -.006 \\
\hline & FCFO & -.589 & .044 & -.550 & -13.326 & .000 & -.675 & -.502 \\
\hline & FS & .008 & .002 & .149 & 3.44 & .001 & .003 & .013 \\
\hline & FL & -.056 & .016 & -.159 & -3.591 & .000 & -.087 & -.025 \\
\hline
\end{tabular}

Note: a. Dependent Variable: EM

Table 9 proved that $\mathrm{Z}$ score, free cash flow from operations, financial leverage and firm size had a significant relationship with earnings management at $\alpha=.05$ ( $p<.001)$. Hence, in this study, $\mathrm{Z}$ score, free cash flow from operations, financial leverage and firm size made a unique and statistically significant contribution to the relationship of earnings management engaged in a company by using discretionary accruals.

The $\mathrm{Z}$ score (standardized $\beta=-0.124$ ) value indicated that as the company is categorized as Non-Financial Distress 
company, earnings management increased by 0.124 times using discretional accruals. It means that non-financial distress companies as identified by $\mathrm{Z}$ scores tend to engage earnings management, compared to financial distress companies. In another words, the more a company experienced a financial distress condition, the less the tendency for it to engage earnings management and vice versa. Thus, H1 is supported based on this result. The result produced was similar to previous studies where a healthier company tended to engage more in earning management compared to a financially distressed company (Agrawal \& Chatterjee, 2015; Hassanpour \& Ardakani, 2017; Humeedat, 2018; Kazemian et al., 2017; Qin \& Ren, 2017). The free cash flow from operations had a negative relationship, which means the more cash flow free from operation, the less earnings management from discretional accruals. This finding is in support of H2 and similar to the studies made by Susanto, Pradipta, and Djashan (2017), Agustia (2013); Winingsih (2017); Yogi and Damayanthi (2016). For financial leverage, the increase in financial leverage caused earnings management to decrease as the relationship is negative. This means that an average increase in debt over total asset by one percent will decrease the earnings management by an average of RM3.30. The finding from this study is different from previous studies made where there was a positive relationship between earnings management and debt ratio (Ghazali et al., 2015; Humeedat, 2018; Mohammadi \& Amini, 2016), hence in support of H3. Finally, firm size has a positive relationship where the bigger the size of a company, the higher the engagement of earnings management on average. The findings on this study similar to Darmawan (2015) and Ali et al. (2015) and in support of H4. Therefore, the model of the study can be summarised as below:

$$
\mathrm{EM}=-0.114-0.020(\mathrm{Z} \text { score })+0.008(\mathrm{FS})-0.056(\mathrm{FL})-0.589(\mathrm{FCFO})+€
$$

Where:

$\mathrm{Z}$ score $=$ Financial Distress (Altman Z score);

FS = Firm's Size;

$\mathrm{FL}=$ Financial Leverage;

$\mathrm{FCFO}=$ Free cash Flow from Operation;

$€=$ Random error.

\section{Conclusion}

This study focused in assessing the potential relationship between financial distress condition experienced by Industrial Product Sector's companies of Malaysian Bourse and their engagement in earnings management practice. In another words, to understand whether earnings management tool may have been used to camouflage financial distress condition experienced by companies to fulfil stakeholders' expectations. In addition, this study also examined potential relationship between firm's free cash flow from operations, leverage and size with earnings management. The motivation of this study is based on the fact that limited research of similar kind had focused on companies listed on Industrial Product Sector of Bursa Malaysia, despite being critical in nation's transformation to become developed country and as the main contributor to the nation's GDP with largest market capitalization value in local bourse. Hence, the findings will be beneficial to stakeholders having interest on industrial product sector companies within developing countries, mainly shareholders and financial institutions to understand the extent of earnings management committed to cover financial distress condition to assist in their decision making. Multiple regression models were developed with all of its conditions and assumptions being fulfilled to test this relationship.

The findings revealed that all hypotheses developed were supported, with financial distress condition of industrial product companies showing significant negative relationship with earnings management, instead of positive. This also mean that industrial product companies which already experiencing financial distress have lower tendency to engage earnings management, in contrast to those not facing financial distress which have higher tendency to engage earnings management. This may be due to the fact that financial healthy companies have potential to grow and in need of more capital to expand faster, thus have high tendency to engage earnings management to pull in more funding from stakeholders. Nevertheless, financial distress companies were having problems to settle their existing financing debts and may not foresee the potential to grow further except for the needs of funding to maintain their survivability. Hence, engagement in earnings management may not be a priority as growth is not expected, but more on securing rescue funding. Furthermore, this was supported by the finding that financial leverage has significant negative relationship with earnings management, which mean the higher leverage already taken by industrial product companies, the lesser their tendency to engage earnings management, as higher leverage is a precursor to financial distress condition. Results also revealed significant negative relationship between free cash flow from operations of industrial product companies and earnings management practice. This may also mean industrial product companies would not engage earnings management when having abundance cash flow to support their growth. Thus, Industrial 
Product companies do not engage earnings management for the purpose of camouflaging its financial distress condition, but may be more for the purpose of supporting growth needs of financing, especially when their existing cash flow are not abundance. This study limitation was that it only covers period of 2016 until 2017 and focuses specifically on companies listed within industrial product sector of Malaysian Bourse. In addition, earnings management was measured based on discretionary accrual as per Jones model and this study excluded other qualitative independent variables such as CEO duality, manager compensation and board structure that were believed to influence management engagement in earnings management. This study can be extended to include other companies listed in the main board of Bursa Malaysia and the period of the study should be extended. In addition, both accruals and real earnings management would be better to be included in future studies to understand the engagement of the manager in earnings management. Finally, future research should also include other qualitative independent variables to understand how the management structure can affect earnings management.

\section{References}

Abd, M., Aziz, E., \& Kassem, R. (2010). Fraudulent financial reporting: do red flags really help?. Auditing, (82), 69-80. https://doi.org/10.19030/iber.v8i9.3163

Aghghaleh, S. F., Mohamed, Z. M., \& Rahmat, M. M. (2016). Detecting financial statement frauds in malaysia: comparing the abilities of beneish and dechow models. Asian Journal of Accounting and Governance. https://doi.org/10.17576/AJAG-2016-07-05

Agrawal, K., \& Chatterjee, C. (2015). Earnings management and financial distress: evidence from India. Global Business Review, 16(5), 140S-154S. https://doi.org/10.1177/0972150915601928

Agustia, D. (2013). Pengaruh faktor good corporate governance, free cash flow, dan leverage terhadap manajemen laba. Jurnal Akuntansi dan Keuangan, 15(1), 27-42.

Ajina, A., \& Habib, A. (2017). Examining the relationship between earning management and market liquidity. Research in International Business and Finance, 42, 1164-1172. https://doi.org/10.1016/j.ribaf.2017.07.054

Ali, U., Noor, M., Khurshid, M. K., \& Mahmood, A. (2015). Impact of firm size on earnings management: A study of textile sector of Pakistan. European Journal of Business and Management, 7(28).

Altman, E. (2000). Predicting financial distress of companies: revisiting the z-score and zeta. Handbook of Research Methods and Applications in Empirical Finance (Vol. 5, pp. 428-456). Edward Elgar Publishing.

Aman, A., Pourjalali, H., \& Teruya, J. (2006). Earnings management in Malaysia: A study on effects of accounting choices. Malaysian Accounting Review, 5(1), 185-209.

Anagnostopoulou, S. C., \& Tsekrekos, A. E. (2017). The effect of financial leverage on real and accrual-based earnings management. Accounting and Business Research, 47(2), 191-236. https://doi.org/10.1080/00014788.2016.1204217

Astuti, A. Y., Nuraina, E., \& Wijaya, A. L. (2017). Pengaruh Ukuran Perusahaan dan Leverage Terhadap Manajemen Laba. Paper presented at the FIPA: Forum Ilmiah Pendidikan Akuntansi.

Barkhordar, M., \& Tehrani, R. (2016). Investigating the effect of free cash flow, dividend and financial leverage on earnings management in listed companies in Tehran Stock Exchange. International Journal of Humanities and Cultural Studies (IJHCS), 1(1), 124-143.

Beslic, I., Beslic, D., Jaksic, D., \& Andric, M. (2015). Testing the models for detection of earnings management. Industrija. https://doi.org/10.5937/industrija43-8035

Bhardwaj, A. (2018). Financial leverage and firm's value: A study of capital structure of selected manufacturing sector firms in India.

Bukit, R. B., \& Nasution, F. N. (2015). Employee diff, free cash flow, corporate governance and earnings management. Procedia-Social and Behavioral Sciences, 211, 585-594. https://doi.org/10.1016/j.sbspro.2015.11.077

Bursa Malaysia. (2018b). PN17 and GN3 companies bursa Malaysia market. Retrieved from http://www.bursamalaysia.com/market/listed-companies/list-of-companies/pn17-and-gn3-companies/

Carr, L. T. (1994). The strengths and weaknesses of quantitative and qualitative research: what method for nursing?. Journal of Advanced Nursing, 20(4), 716-721.

Chang, K., Kang, E., \& Li, Y. (2016). Effect of institutional ownership on dividends: An agency-theory-based 
analysis. Journal of Business Research, 69(7), 2551-2559. https://doi.org/10.1016/j.jbusres.2015.10.088

Chowdhury, A., Mollah, S., \& Al Farooque, O. (2018). Insider-trading, discretionary accruals and information asymmetry. The British Accounting Review, 50(4), 341-363. https://doi.org/10.1016/j.bar.2017.08.005

Chu, E., \& Song, S.-I. (2010). Information asymmetry and earnings management: Causes of inefficient investment in Malaysia.

Dang, C., Li, Z., \& Yang, C. (2018). Measuring firm size in empirical corporate finance. Journal of Banking \& Finance, 86, 159-176. https://doi.org/10.1016/j.jbankfin.2017.09.006

Darmawan, A. (2015). Pengaruh diversifikasi operasi, diversifikasi geografis dan ukuran perusahaan terhadap manajemen laba: studi empiris pada perusahaan manufaktur sektor consumer goods industry yang terdaftar di bursa efek indonesia periode 2010-2013.

DeAngelo, H., DeAngelo, L., \& Skinner, D. J. (1994). Accounting choice in troubled companies. Journal of Accounting and Economics, 17(1-2), 113-143.

Dechow, P. M., \& Skinner, D. J. (2000). Earnings management: reconciling the views of accounting academics, practitioners, and regulators. Accounting Horizons, 14(2), 235-250. https://doi.org/10.2308/acch.2000.14.2.235

Dechow, P. M., Sloan, R. G., \& Sweeney, A. P. (1995). Detecting earnings management. The Accounting Review, 70(2), 193-225.

Dewi, R. P., \& Priyadi, M. P. (2016). Pengaruh free cash flow, kinerja keuangan terhadap earnings management dimoderasi corporate governance. Jurnal Ilmu dan Riset Akuntansi, 5(2).

Dharan, B. G., \& Bufkins, W. R. (2008). Red flags in enron's reporting of revenues \& key financial measures. SSRN Electronic Journal, (7), 97-112. https://doi.org/10.2139/ssrn.1172222

Farrelly, N., King, A., Wesley, M., \& White, H. (2017). Muddy boots and smart suits: researching Asia-Pacific affairs. ISEAS - Yusof Ishak Institute.

Field, A. (2009). Discovering statistics using SPSS. Sage publications.

Ghazali, A. W., Shafie, N. A., \& Sanusi, Z. M. (2015). Earnings management: an analysis of opportunistic behaviour, monitoring mechanism and financial distress. Procedia Economics and Finance. https://doi.org/10.1016/S2212-5671(15)01100-4

Hamid, F. Z. A., Shafie, R., Othman, Z., Hussin, W. N. W., \& Fadzil, F. H. (2013). Cooking the books: The case of Malaysian listed companies. International Journal of Business and Social Science, 4(13).

Hasnan, S., Rahman, R. A., \& Mahenthiran, S. (2014). Determinants of fraudulent financial reporting: Evidence from Malaysia. Jurnal Pengurusan (UKM Journal of Management), 42.

Hassanpour, S., \& Ardakani, M. M. (2017). The effect of Pre-bankruptcy financial distress on earnings management tools. International Review of Management and Marketing, 7(3), 312-219. https://doi.org/10.1504/IJTGM.2017.082372

Healy, P. M., \& Wahlen, J. M. (1999). A review of the earnings management literature and its implications for standard setting. Accounting Horizons, 13(4), 365-383. https://doi.org/10.2308/acch.1999.13.4.365

Humeedat, M. M. (2018). Earnings management to avoid financial distress and improve profitability: evidence from Jordan. International Business Research, 11(2). https://doi.org/10.5539/ibr.v11n2p222

Islam, M. A., Ali, R., \& Ahmad, Z. (2011). Is Modified jones model effective in detecting earnings management? evidence from a developing economy. International Journal of Economics and Finance. https://doi.org/10.5539/ijef.v3n2p116

Jensen, M. C. (1986). Agency Costs of free cash flow, corporate finance, and takeovers. The American Economic Review, 76(2), 323-329.

Jensen, M. C., \& Meckling, W. H. (1976). Theory of the firm: Managerial behavior, agency costs and ownership structure. Journal of Financial Economics, 3(4), 305-360. https://doi.org/10.1016/0304-405X(76)90026-X

Jiraporn, P., Miller, G. A., Yoon, S. S., \& Kim, Y. S. (2008). Is earnings management opportunistic or beneficial? An agency theory perspective. International Review of Financial Analysis, 17(3), 622-634. https://doi.org/10.1016/j.irfa.2006.10.005

Jones, J. J. (1991). Earnings management during import relief investigations. Journal of Accounting Research, 29(2), 
193.

Kamal, M. E. M., Salleh, M. F. M., \& Ahmad, A. (2019). Management fraud propensity factors, governance interactions and earnings manipulation: A case of malaysian public listed companies. International Journal of Recent Technology and Engineering, 8(3), 8649-8663. https://doi.org/10.35940/ijrte.C6455.098319

Kangarluei, S. J., Motavassel, M., \& Abdollahi, T. (2011). The investigation and comparison of free cash flows in the firms listed in Tehran Stock Exchange (TSE) with an emphasis on earnings management. International Journal of Economics and Business Modeling, 2(2), 118.

Kazemian, S., Shauri, N. A. A., Sanusi, Z. M., Kamaluddin, A., \& Shuhidan, S. M. (2017). Monitoring mechanisms and financial distress of public listed companies in Malaysia. Journal of International Studies, 10(1), 92-109. https://doi.org/10.14254/2071-8330.2017/10-1/6

Kighir, A., Omar, N., \& Mohamed, N. (2014). Earnings management detection modeling: A methodological review. World Journal of Social Sciences Issue, 4(1), 18-32.

Kim, Y., Liu, C., \& Rhee, S. (2003). The relation of earnings management to firm size.

Kothari, S. P., Leone, A. J., \& Wasley, C. E. (2005). Performance matched discretionary accrual measures. Journal of Accounting and Economics, 39(1), 163-197. https://doi.org/10.1016/j.jacceco.2004.11.002

Leuz, C., Nanda, D., \& Wysocki, P. D. (2003). Earnings management and investor protection: an international comparison. Journal of Financial Economics, 69(3), 505-527.

Llukani, T. (2013). Earnings management and firm size: An empirical analyze in Albanian market. European Scientific Journal, ESJ, 9(16).

Lourenço, I. C., Rathke, A., Santana, V., \& Branco, M. C. (2018). Corruption and earnings management in developed and emerging countries. Corporate Governance: The International Journal of Business in Society, 18(1), 35-51. https://doi.org/10.1108/CG-12-2016-0226

Malcolm, S. (2003). Research methods in accounting. SAGE Publications.

Mohammadi, F., \& Amini, P. (2016). Investigating the Relationship between Financial Distress and Earnings Management in Corporations of Accepted in Tehran Stock Exchange. International Academic Journal of Accounting and Financial Management, 3(6), 41-50.

Muljono, D. R., \& Suk, K. S. (2018). Impacts of financial distress on real and accrual earnings management. Jurnal Akuntansi, 22(2). https://doi.org/10.24912/ja.v22i2.349

Nagar, N., \& Sen, K. (2016). Earnings management strategies during financial distress (pp. 1-42).

Neifar, S., Halioui, K., \& Ben Abdelaziz, F. (2016). The motivations of earnings management and financial aggressiveness in American firms listed on the NASDAQ 100. Journal of Applied Accounting Research, 17(4), 397-420.

Nobanee, H., \& Abraham, J. (2017). The impact of free cash flow, equity concentration and agency costs on firm's profitability.

Outecheva, N. (2007). Corporate financial distress: An empirical analysis of distress risk.

Pallant, J. (2013). SPSS survival manual. McGraw-Hill Education (UK).

Persons, O. (2011). Using financial statement data to identify factors associated with fraudulent financial reporting (Vol. 11).

Qin, Z., \& Ren, X. (2017). Distress risk and earnings management.

Quy, V. T., \& Nhan, D. T. (2017). Detecting Earning Management of Companies Listing on HOSE. Asian Journal of Social Sciences and Management Studies. https://doi.org/10.20448/journal.500.2017.42.82.87

Rădăşanu, A. C. (2015). Cash-flow sustainable growth rate models. Journal of Public Administration.

Rahman, R. A., Sulaiman, S., Fadel, E. S., \& Kazemian, S. (2016). Earnings management and fraudulent financial reporting: the malaysian story. Journal of Modern Accounting and Auditing, 12(2), 91-101. https://doi.org/10.17265/1548-6583/2016.02.003

Roychowdhury, S. (2006). Earnings management through real activities manipulation. Journal of Accounting and Economics, 42(3), 335-370. 
Rusmin, R., Emita, W., \& Hartadi, A. B. (2014). The impact of surplus free cash flow and audit quality on earnings management: The case of growth triangle countries. Asian Review of Accounting, 22(3), 217-232. https://doi.org/10.1108/ARA-10-2013-0062

Sadique, R. B. M. (2016). Corporate fraud: an empirical analysis of corporate governance and earnings management in Malaysia. Unpuplished Thesis, Lincoln University, 1-228. https://doi.org/10.1007/s11104-010-0533-9

Savin, N. E., \& White, K. J. (1977). The durbin-watson test for serial correlation with extreme sample sizes or many regressors. Econometrica, 45(8), 1989-1996. https://doi.org/10.2307/1914122

Schipper, K. (1989). Earnings management. Accounting Horizons, 3(4), 91-102.

Sekaran, U. (2013). Research methods for business (Vol. 65).

Sekaran, U., \& Bougie, R. (2016). Research methods for business: a skill building approach. Wiley.

Statista, P. (2016). Malaysia - share of economic sectors in the gross domestic product 2016. Statista Portal.

Susanto, Y. K., Pradipta, A., \& Djashan, I. A. (2017). Free cash flow and earnings management: board of commissioner, board independence and audit quality. Corporate Ownership and Control, 14(4), 284-288. https://doi.org/10.22495/cocv14i4c1art10

Tabachnick, B. G., \& Fidell, L. S. (2007). Using multivariate statistics. Allyn \& Bacon/Pearson Education.

Time. (2018). Chronology of a Collapse - Behind the Enron Scandal.

Winingsih, W. (2017). Pengaruh Free Cash Flow, Leverage, Likuiditas, Profitabilitas, Dan Ukuran Perusahaan Terhadap Manajemen Laba (Studi Empiris pada Perusahaan Manufaktur yang Terdaftar di Bursa Efek Indonesia Periode 2012-2015). Universitas Muhammadiyah Surakarta,

Yogi, L. M. D. P., \& Damayanthi, I. G. A. E. (2016). Pengaruh arus kas bebas, capital adequacy ratio dan good corporate governance pada Manajemen Laba. E-Jurnal Akuntansi, 1056-1085.

\section{Copyrights}

Copyright for this article is retained by the author(s), with first publication rights granted to the journal.

This is an open-access article distributed under the terms and conditions of the Creative Commons Attribution license (http://creativecommons.org/licenses/by/4.0/). 